\title{
ANALISIS POST-HARVEST LOSS PADA OKRA DENGAN METODE OBJECTIVE MATRIX (OMAX) DI PT MITRATANI DUA TUJUH JEMBER
}

\author{
The Analysis of Post-Harvest Loss on Okra Using Objective Matrix Method (OMAX)
} at PT Mitratani Dua Tujuh Jember

\author{
Ida Bagus Suryaningrat ${ }^{1) *}$, Ferry Julio Prabowo ${ }^{1)}$, Winda Amiliaa ${ }^{1)}$ \\ ${ }^{1)}$ Program Studi Teknologi Industri Pertanian, Fakultas Teknologi Pertanian, \\ Universitas Jember \\ Jalan Kalimantan No. 37, Kampus Tegal Boto, Jember, Jawa Timur 68121 \\ *Korespondensi Penulis: suryaningrat.ftp@unej.ac.id
}

\begin{abstract}
Post-harvest loss is a process of the loss or the broken material from production in the field to the food being ready to be consumed. Losses in agricultural or horticultural produce are a major problem in the post-harvest process. Therefore, it was needed to identify the criteria based on the postharvesting process to know the performance level of each criterion provided. This study was aimed to know the post-harvest loss source in the occurrence of the post-harvest process of okra. This research used Objective Matrix method (OMAX) to evaluate the performance level of each criterion provided. AHP method was also implemented in this research by using the pairwise comparison technique to measure the weight on OMAX and fishbone diagram and to identify causes factors of the okra loss. The research result showed that the picking and weighing process during post-harvest okra have lower performance level and it was not meet the expected target of the company (PT Mitratani Dua Tujuh). Other result of okra loss level was also still far from the expected target of the company. The improvement recommendations were needed to reduce post-harvest okra loss, i.e. increasing supervision by the manager, making removal plot during okra harvesting and briefing every morning with the okra picker.
\end{abstract}

Keywords: AHP, fishbone diagram, OMAX, post-harvest loss

\section{PENDAHULUAN}

Okra (Abelmoschus esculentus L.) adalah tanaman tahunan yang dapat memiliki tinggi sampai $2 \mathrm{~m}$, bunganya seperti bunga sepatu dengan buahnya berbentuk lonjong yang memanjang, kerucut pada ujungnya dan berwarna hijau atau merah. Okra dilaporkan memiliki banyak manfaat karena kandungan senyawa fenolik dan flavonoidnya terutama kuersetin dan pitosterol (Hamid et al., 2010; Sa'eed et al., 2016). Menurut Sabitha et al. (2011), kandungan gizi yang terdapat dalam buah okra terdiri dari $1,5 \mathrm{~g}$ protein, $5,8 \mathrm{~g}$ karbohidrat, $37 \mathrm{mg}$ asam folat, $13 \mathrm{mg}$ vitamin $\mathrm{C}(22 \%), 46 \mathrm{mg}$ magnesium $(11,5 \%), 460$ IU vitamin A $(9,2 \%), 2$ g serat $\operatorname{diet}(8 \%), 257 \mathrm{mg}$ potassium (7,3\%), $50 \mathrm{mg}$ kalsium (5\%), dan 0,4 mg besi (2,3\%). Buah okra yang dipanen adalah buah okra yang muda sehingga dapat menjadi sayur dan bukan yang tua karena teksturnya sudah menjadi keras.

Pada saat pemanenan okra, kegiatan pascapanen perlu diperhatikan. Pascapanen hasil pertanian adalah tahapan kegiatan dari pemanenan hasil pertanian (hasil tanaman pangan, hortikultura, perikanan, peternakan dan perkerbunan) sampai hasil tanaman tersebut siap untuk dipasarkan. Penanganan pascapanen harus dilakukan dengan hatihati karena karakteristik bahan pertanian bersifat perishable (mudah rusak) (Kumar et al., 2006). Hal tersebut berpotensi menimbulkan kerugian jika terjadi kegagalan penanganan (post-harvest loss). Post-harvest loss adalah kehilangan pascapanen karena jumlah hasil pertanian hilang saat proses pascapanen (Ramchandra et al., 2015). Seperti pada 
pemanenan sereal di daerah Sahara, Afrika, post-harvest loss terjadi karena jauhnya jarak antara lahan, pasar dan jalan utama serta curah hujan yang tinggi sehingga menyebabkan kerugian karena kerusakan bahan dan serangan hewan pengerat (Hengsdijk and de Boer, 2017). Postharvest loss pada pemanenan sayuran di Allahabad, Uttar Pradesh disebabkan oleh kurangnya infrastruktur, buruknya fasilitas (air, jalan) dan kurangnya manajemen tenaga kerja sehingga cepat terjadi pembusukan sayuran (Ramchandra et al., 2015).

Salah satu sayuran yaitu buah okra yang berwarna hijau, juga dibudidayakan dan dipanen oleh PT Mitratani Dua Tujuh, Indonesia. Buah okra hijau ini akan diekspor dalam bentuk okra blansing. Pada tahun 2017, PT Mitratani Dua Tujuh memiliki target produksi okra sebesar $18.000 \mathrm{~kg} /$ ha untuk raw material (RM) dan $9.000 \mathrm{~kg} / \mathrm{ha}$ untuk grading. Akan tetapi hasil produksi PT Mitratani Dua Tujuh untuk RM (raw material) masih belum memenuhi target. Perusahaan menyadari bahwa masih ditemukan okra yang tidak dipanen selama proses pemanenan. Padahal hal tersebut jika dihitung dapat dijadikan sebagai sebuah potensi untuk menambah jumlah produksi dan keuntungan perusahaan. Okra yang tidak terpanen ini disebut dengan post-harvest loss sehingga perusahaan perlu melakukan identifikasi terhadap faktor penyebab post-harvest loss pada okra. Analisis tingkat kinerja perlu dilakukan untuk mengetahui faktor manakah yang memiliki tingkat kinerja buruk dan berpotensi menyebabkan postharvest loss pada okra.

Salah satu metode yang dapat digunakan untuk mengukur tingkat kinerja pada saat pascapanen berlangsung adalah dengan menggunakan metode objective matrix (OMAX). Analisis produktivitas untuk mempertahankan dan mengetahui eksistensi industri di bidang Die Casting dalam membuat spare part PT Marodan Berlian Sakti juga menggunakan metode
OMAX sehingga diketahui pada bulan Oktober, produktivitas yang dihasilkan tinggi mencapai 94,33\% (Fithri dan Firdaus, 2014). Oleh karena itu analisis kehilangan pascapanen (post-harvest loss) okra pada penelitian ini menggunakan metode objective matrix (OMAX) untuk mengetahui tingkat kehilangan serta cara penanggulangannya agar dapat mengurangi tingkat kerugian pada perusahaan. Maka tujuan dari penelitian ini adalah untuk menentukan dan mengidentifikasi KPI (key performance indicator) proses pascapanen okra, menganalisis tingkat atau taraf kehilangan pada saat pascapanen (postharvest loss) okra menggunakan metode objective matrix (OMAX). Selain itu juga merumuskan rancangan perbaikan proses pascapanen okra untuk menurunkan taraf post-harvest loss selama pemanenan.

\section{METODE PENELITIAN}

\section{Alat dan Bahan}

Penelitian ini dilakukan di area 8 PT Mitratani Dua Tujuh Jember dengan lokasi lahan berada di Curahrejo Kecamatan Ajung Kabupaten Jember. Alat yang digunakan adalah timbangan, pisau, penggaris, kamera, dan menggunakan software Expert Choice. Selama pengambilan data, diperlukan kuisioner yang selanjutnya dibutuhkan dalam perhitungan terhadap jumlah kehilangan yang terjadi pada saat proses pascapanen berlangsung.

\section{Metode Pengumpulan Data}

Pengumpulan data dilakukan dengan cara pengamatan langsung yaitu melakukan observasi langsung ke lokasi lahan yang berada di Curahrejo Kecamatan Ajung Kabupaten Jember, melakukan wawancara pada pekerja petik (pemetik) okra dan dokumentasi. Pengambilan sampel dilakukan dengan menggunakan purposive sampling method yaitu penentuan sampel yang berdasarkan tingkat pengalaman pekerja. Sampling dipakai dalam 
mempermudah pengumpulan data untuk mengamati berapa kehilangan yang terjadi pada saat proses pascapanen okra. Rumus sampling yang digunakan menggunakan teknik Slovin dikarenakan dalam pengambilan sampel jumlahnya harus representatif agar hasil penelitian dapat digeneralisasikan dan dalam perhitungannya tidak memerlukan tabel jumlah sampel, dan hanya dilakukan dengan perhitungan sederhana.

\section{Penentuan Jumlah Pekerja Petik}

Pada penelitian ini penentuan sampel jumlah responden dilakukan terhadap pekerja petik yang telah memiliki pengalaman lebih dari 3 tahun dalam memetik okra. Proses pemetikan buah okra dilakukan oleh 50 orang pekerja petik, kemudian dilakukan sampling menggunakan persamaan Slovin berdasarkan pengalaman kerja pemetik lebih dari 3 tahun. Maka rumusnya didapatkan sebagai berikut :

$$
\begin{aligned}
& n=\frac{N}{1+N(e)^{2}} \\
& n=\frac{50}{1+50(10 \%)^{2}} \\
& n=33,33
\end{aligned}
$$

Keterangan: $\mathrm{n}=$ jumlah sampel; $\mathrm{N}=$ jumlah populasi (pemetik yang berpengalaman > 3 tahun); $e=$ persen batas kesalahan (10\%)

Berdasarkan hasil perhitungan menggunakan rumus slovin dihasilkan $\mathrm{n}=$ 33,33 dengan batas kesalahan yang bisa ditolerir sebesar $10 \%$ dan tingkat kepercayaan sebesar 90\%. Dengan kata lain jumlah sampel yang diambil untuk pekerja petik adalah sebanyak 33 orang berdasarkan latar belakang umur pekerja petik okra (Gambar 1).

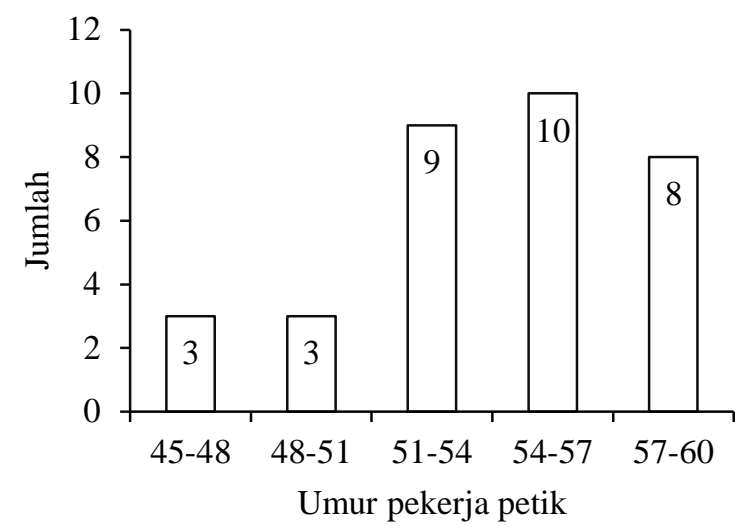

Gambar 1. Jumlah pekerja petik okra berdasarkan latar belakang umur

Jumlah pemetik okra selama pemanenan untuk rentang usia 57-60 sejumlah 8 orang pekerja petik, untuk rentang usia 54-57 sejumlah 10 orang pekerja petik, untuk rentang usia 51-54 sejumlah 9 orang, rentang usia 48-51 sejumlah 3 orang, dan rentang usia 45-48 sejumlah 3 orang pekerja petik (Gambar 1). Pekerja petik yang dipilih juga memiliki pengalaman berkerja sebagai pekerja petik okra lebih dari 3 tahun.

\section{Analisis Data}

Data yang diperoleh dianalisis menggunakan metode objective matrix (OMAX) untuk mengetahui kehilangan pascapanen (post-harvest loss) buah okra. Langkah-langkah yang dilakukan mengacu pada langkah-langkah OMAX, yaitu menentukan kriteria dalam peningkatan produktivitas bahan baku okra, dan menentukan indikator produktivitas dalam bentuk rasio untuk masing-masing kriteria produktivitas. Menurut Hamidah et al. (2013), langkah-langkah dalam menyusun OMAX adalah sebagai berikut :

\section{Menentukan Kriteria}

Tahap identifikasi kriteria atau KPI (key performance indicator) menggunakan tahapan-tahapan yang terjadi pada saat proses pascapanen okra berlangsung dan berdasarkan faktor penyebab terjadinya post-harvest loss pada okra. 
2. Perhitungan Rasio Performa

Performa yang dicapai perusahaan diperolah dari tiap rasio kriteria yang akan diukur dari data-data tiap kriteria. Kriteria yang diukur adalah pemetikan, penimbangan dan pengangkutan.

3. Penentuan Skala Pengukuran (Level skor $0,3,10$ )

Cara pengisian skor sebagai berikut:

a) Level 10, yaitu nilai yang diharapkan atau diinginkan oleh perusahaan

b) Level 3, yaitu rata-rata yang dicapai perusahaan yang dihitung selama periode pengukuran

c) Level 0 , yaitu nilai produktivitas yang terburuk yang terjadi selama periode pengukuran berlangsung.

4. Menetukan Nilai Aktual (Skala 1-2 dan 4-9).

Nilai aktual merupakan nilai yang mungkin dicapai sebelum sasaran akhir. Cara penentuannya sebagai berikut:

a) Interval 1-2 =

$$
\frac{\text { Level } 3-\text { Level } 0}{(3-0)}
$$

b) Interval 4-9=

$$
\frac{\text { Level } 10-\text { Level } 3}{(10-3)}
$$

5. Menetukan Score, Weight, Nilai, dan Menghitung Performa Indikator

a) Skor merupakan level yang menunjukan nilai (performance) pada saat pengukuran. Setiap kriteria memiliki tingkat kepentingan berbeda sehingga perlu dilakukan pembobotan (weight) pada setiap kriteria.

b) Bobot diperoleh berdasarkan hasil pembobotan dengan menggunakan metode AHP (Analytical Hierarchy Process) dengan teknik pairwise comparison (perbandingan berpasangan) dan dihitung menggunakan software expert choice.

c) Nilai merupakan hasil perkalian antara skor dan bobot pada setiap kriteria yang diukur. Hasil penjumlahan nilai dari seluruh kriteria digunakan untuk mengetahui nilai total perusahaan.

Penentuan kategori terhadap level 010 yang ada pada KPI dengan menggunakan asumsi sebagai berikut yaitu level 0-3 (buruk), level 4-7 (cukup), dan level 8-10 (baik). Penentuan level ini berdasarkan penelitian Winda (2013) yang juga meneliti tentang kinerja perusahaan dan karyawan dan hasilnya menunjukkan bahwa melalui metode objective matriks dapat memberikan informasi bahwa kinerja perusahaan PT Jagung Hibrida Sulawesi masih lebih rendah dibandingkan target karena nilai OMAX masih di bawah 3 .

\section{HASIL DAN PEMBAHASAN}

\section{Penyusunan KPI Pascapanen Okra}

KPI (key performance indicator) sebagai indikator yang dapat memberikan informasi mengenai kemajuan perusahaan. Pada penelitian ini, KPI disusun berdasarkan alur proses pascapanen okra yang berlangsung di PT Mitra Tani Dua Tujuh agar dapat mengetahui tingkat kinerja pada saat proses pascapanen okra. Terdapat 3 KPI (key performance indicator) antara lain KPI pemetikan, KPI penimbangan, dan KPI pengangkutan. Dalam melakukan penyusunan KPI beberapa langkah yang dilakukan yaitu pertama merancang fishbone diagram (diagram tulang ikan) untuk menentukan kriteria dalam setiap KPI yang ada. Selanjutnya melakukan identifikasi KPI dan melakukan pembobotan. Beberapa faktor penyebab terjadinya post-harvest loss juga telah diketahui melalui pengisian kuisioner. Faktor-faktor tersebut kemudian disusun ke dalam diagram tulang ikan (fishborne diagram) (Gambar 2).

Identifikasi key performance indicator untuk pemetikan dilakukan dengan meninjau terlebih dahulu terhadap faktor-faktor yang menyebabkan terjadinya post-harvest loss pada pemetikan, 


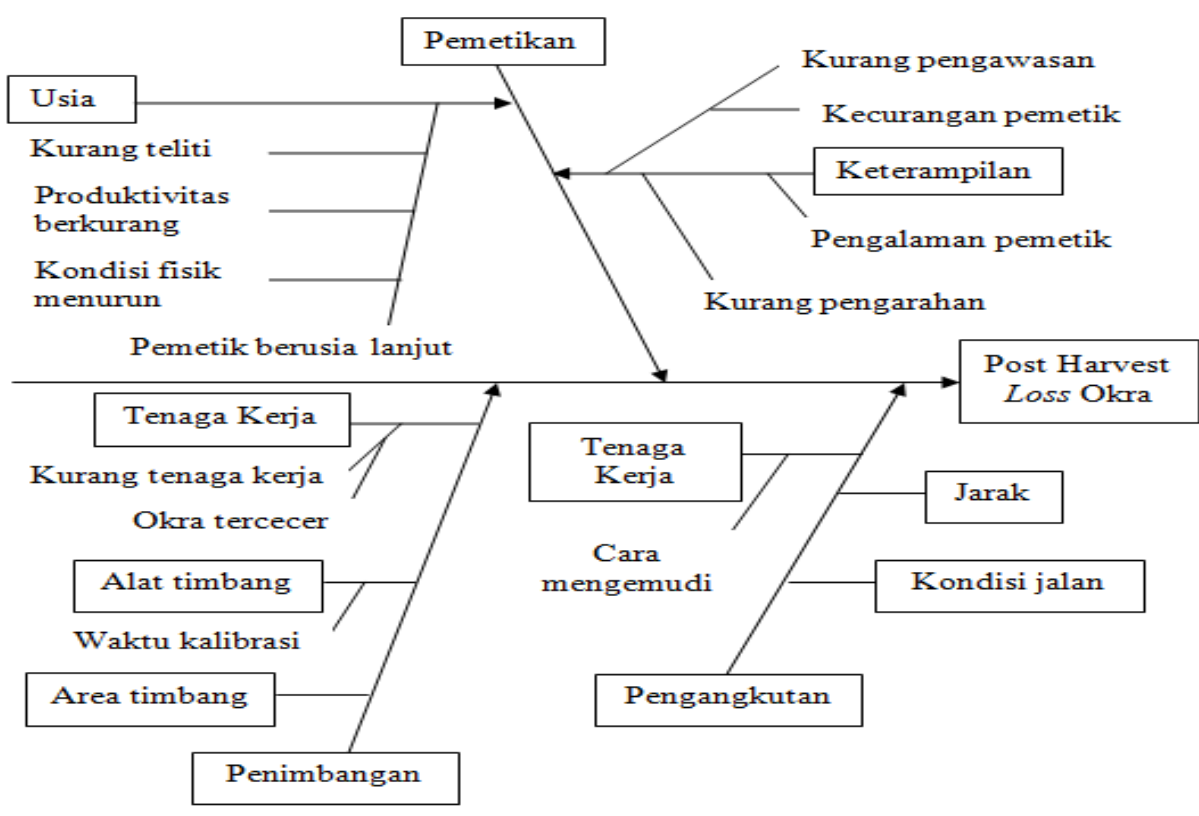

Gambar 2. Diagram tulang ikan tentang faktor penyebab post-harvest loss selama pemanenan okra

pengangkutan dan penimbangan. Berdasarkan hasil diskusi dengan pihak terkait (manager area 8 dan asisten manager area 8) diperoleh informasi bahwa usia menjadi penyebab terjadinya post-harvest loss pada pemetikan. Hal ini dikarenakan masih banyaknya pekerja petik berusia lanjut yang menyebabkan turunnya tingkat ketelitian dan turunnya kondisi fisik. Selain itu juga kurangnya pengawasan dan indikasi kecurangan pemetik juga menjadi faktor penyebab post-harvest loss okra (Gambar 2). Kemudian dilakukan pengukuran terhadap tingkat kinerja berdasarkan kategori usia yang telah dikelompokkan dengan range pengalaman kerja lebih dari 3 tahun agar pengelompokkan usia tidak melebar.

Identifikasi key performance indicator untuk penimbangan dilakukan dengan mempertimbangkan faktor-faktor yang menyebabkan terjadinya post-harvest loss pada penimbangan. Dari hasil identifikasi tersebut maka diperoleh faktor tenaga kerja dan alat timbang yang menjadi indikator pengukuran kinerja. Pada faktor tenaga kerja, pengukuran dilakukan dengan cara menghitung jumlah kehilangan okra yang ada pada area penimbangan. Pada faktor alat timbang pengukuran kinerja dengan cara mengukur waktu setiap berapa lama alat timbang dilakukan kalibrasi. Identifikasi key performance indicator untuk pengangkutan dilakukan dengan meninjau terlebih dahulu faktor yang menyebabkan terjadinya post-harvest loss pada pengangkutan. Hasil identifikasi KPI pengangkutan terhadap post-harvest loss okra menunjukkan bahwa ketiga faktor yang ada dapat menjadi indikator pengukuran. Caranya adalah dengan mengukur berapa banyak okra yang tercecer kemudian rusak saat proses pengangkutan berlangsung dari lahan hingga pabrik.

Setelah mengidentifikasi KPI kemudian dilakukan pembobotan terhadap kriteria yang telah ditentukan untuk mengetahui pengaruh kinerja masingmasing kriteria yang ada terhadap perusahaan. Pembobotan ini dilakukan menggunakan matriks pairwise comparison sebagai bagian dari metode AHP. Metode AHP digunakan karena dapat memberikan strategi yang tepat dalam 
proses seleksi pengambilan keputusan (Suryaningrat dan Fianeka, 2017).

Setelah kuisioner diisi oleh expert yang ada (manager area 8 dan asisten manager area 8), maka selanjutnya pembobotan dihitung menggunakan bantuan software Expert Choice. Dari pengukuran tersebut didapatkan angka inconsistency ratio sebesar 0,02 . Nilai ini lebih kecil dibandingkan nilai inconsistency ratio yang dapat diterima yaitu sebesar 0,1 sehingga hasil pembobotan ini dapat diterima. Berdasarkan nilai pembobotan (Tabel 1), perusahaan memprioritaskan pemetikan sebagai kriteria yang memiliki pengaruh terbesar terhadap loss yang dihasilkan saat proses pascapanen okra berlangsung karena nilai bobot sebesar 0,7124 . Selanjutnya adalah penimbangan dengan bobot 0,1986 dan terendah adalah pengangkutan dengan bobot 0,0891 .

Tabel 1. Nilai pembobotan terhadap KPI (key performance indicator)

\begin{tabular}{clc}
\hline No. & Kriteria & Bobot \\
\hline 1. & Pemetikan & 0,7124 \\
2. & Penimbangan & 0,1986 \\
3. & Pengangkutan & 0,0891 \\
\hline & Total & 1 \\
\hline
\end{tabular}

\section{OMAX (Objective Matrix) Pascapanen Okra}

Objective matrix (OMAX) adalah suatu metode untuk melakukan pengukuran kinerja terhadap setiap bagian yang ada. Langkah-langkah yang dilakukan dalam mengukur tingkat kinerja pertama dengan menentukan level 0, 3, dan 10 dalam matriks OMAX berdasarkan data jumlah kehilangan pascapanen, serta menentukan nilai performance yang ada. Kemudian dilanjutkan dengan melakukan penyusunan OMAX untuk mengetahui tingkat kinerja pada area 8 PT Mitratani Dua Tujuh pada lokasi Curahrejo.

Berdasarkan data jumlah kehilangan pascapanen yang dihasilkan terhadap kriteria-kriteria yang ada dalam KPI, maka dapat ditentukan level 0 yaitu berdasarkan data terburuk, level 3 berdasarkan rata-rata keseluruhan data, dan level 10 berdasarkan data target perusahaan.

Tabel 2. Post-harvest loss okra

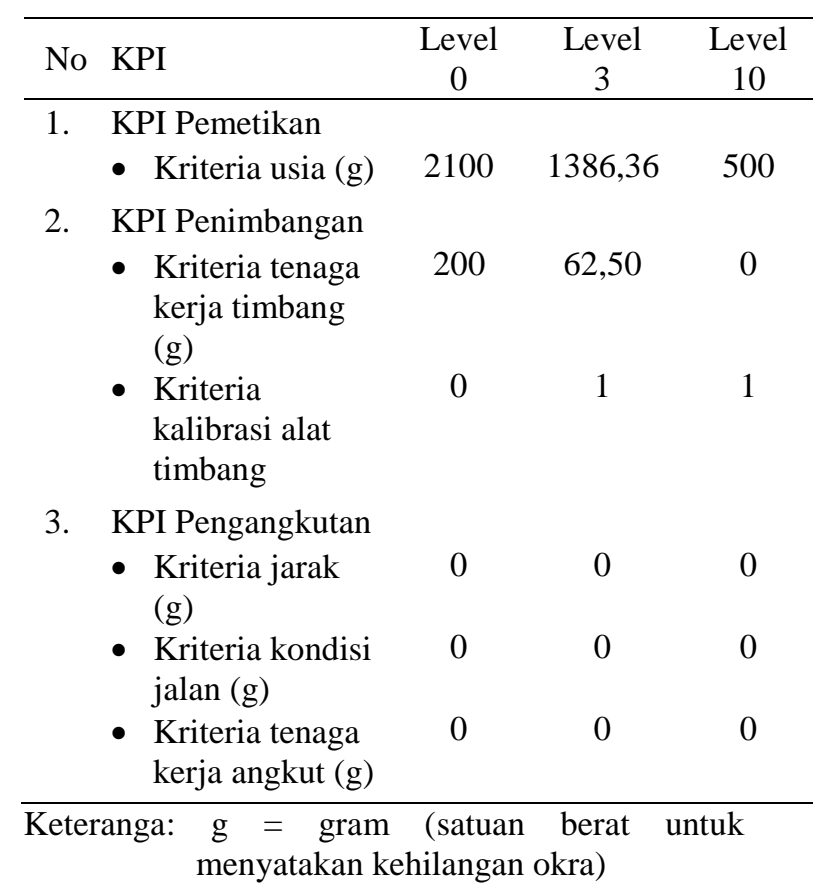

Tabel 2 menunjukkan bahwa pada KPI pemetikan untuk kriteria usia didapatkan jumlah loss sebesar $2100 \mathrm{~g}$ kemudian nilai tersebut diletakkan pada level 0 dari matriks OMAX. Nilai selama pengukuran adalah sebesar 1386,36 g yang selanjutnya diletakkan pada level 3 dari matriks OMAX. Level 10 dalam matriks OMAX merupakan target yang dinginkan oleh perusahaan, yaitu target loss pada pemetikan maksimal adalah sebesar $500 \mathrm{~g}$.

Pada KPI penimbangan untuk kriteria tenaga kerja timbang diketahui bahwa jumlah loss terbanyak sebesar $200 \mathrm{~g}$ yang kemudian diletakkan pada level 0 matriks OMAX. Rata-rata loss penimbangan sebesar 62,5 g yang kemudian diletakkan pada level 3 matriks OMAX. Pada level 10 dalam matriks OMAX, perusahaan menargetkan sebesar 0 yang artinya tidak boleh ada loss yang terjadi pada saat proses penimbangan berlangsung. Pada kriteria 
kalibrasi alat timbang level 0 atau nilai yang terburuk dalam matriks OMAX adalah sebesar 0 yang artinya alat timbang tidak pernah dilakukan kalibrasi. Level 3 atau nilai rata-rata pada matriks OMAX adalah sebesar 1 karena rata-rata dalam 5 tahun terakhir PT Mitratani Dua Tujuh melakukan kalibrasi alat setahun sekali (Tabel 2). Untuk menentukan level 10 dalam matriks OMAX berdasarkan literatur yang ada, menurut Sholihah (2016) mengatakan bahwa kegiatan kalibrasi terhadap berbagai alat ukur khususnya timbangan sebaiknya dilakukan setiap 1 tahun sekali. Oleh karena itu Level 10 atau nilai pada matriks OMAX sebesar 1 .

Pada KPI pengangkutan untuk keseluruhan kriteria tidak ditemukan adanya okra yang hilang atau loss pada saat proses pengangkutan berlangsung. Jadi untuk level 0 dan level 3 pada matrix OMAX adalah sebesar $0 \mathrm{~g}$, dan untuk level 10 OMAX sebesar 0 g (Tabel 2). Hal ini terjadi karena pada saat proses pengangkutan dari lahan ke pabrik sejauh 8 $\mathrm{km}$, okra diangkut menggunakan keranjang yang telah disediakan oleh pabrik yang kemudian ditaruh ke dalam bak mobil pick up. Kemudian ditutup rapat dengan terpal bertujuan untuk menjaga okra dari paparan sinar matahari langsung dan menjaga okra agar tidak tercecer di jalan.

Pada KPI pemetikan, nilai performance dibedakan berdasarkan pengelompokkan usia pemetik (Gambar 3). Semakin tua umur pemetik maka jumlah loss semakin besar. Gambar 3 merupakan nilai performance dalam matrix OMAX untuk menentukan tingkat kinerja pada proses pemetikan berdasarkan rentang umur yang ada.

Dalam menentukan nilai performance untuk KPI penimbangan untuk kriteria tenaga kerja terhadap jumlah loss yang dihasilkan pada saat proses penimbangan berlangsung dilakukan 3 kali pengukuran. Hal ini dilakukan untuk mendapatkan nilai yang lebih optimal untuk menentukan tingkat kinerja yang dihasilkan dalam proses pascapanen di lahan area 8 yang berlokasi di Curahrejo. Nilai performance KPI penimbangan ditunjukkan oleh Tabel 3.

Tabel 3. Nilai performance penimbangan

\begin{tabular}{lcccc}
\hline Kriteria & $\begin{array}{l}\text { Pengu- } \\
\text { kuran } \\
\text { ke-1 }\end{array}$ & $\begin{array}{l}\text { Pengu- } \\
\text { kuran } \\
\text { ke-2 }\end{array}$ & $\begin{array}{l}\text { Pengu- } \\
\text { kuran } \\
\text { ke-3 }\end{array}$ & Nilai \\
\hline $\begin{array}{l}\text { Tenaga } \\
\text { kerja }\end{array}$ & 0 & 50 & 50 & 33,33 \\
\hline
\end{tabular}

Kriteria tenaga kerja terhadap loss yang dihasilkan pada saat proses penimbangan pada pengukuran pertama tidak terdapat adanya loss yang terjadi, tetapi pada pengukuran ke-2 dan ke-3 ditemukan loss yang terjadi seperti adanya okra yang tercecer lalu terinjak-injak sebesar 50 gram (Tabel 3). Dalam menentukan nilai performance untuk dimasukkan ke dalam matriks OMAX, didapatkan dari jangka waktu kalibrasi alat timbang pada tahun 2018 yang juga dilakukan dalam 1 tahun sekali. Pada KPI

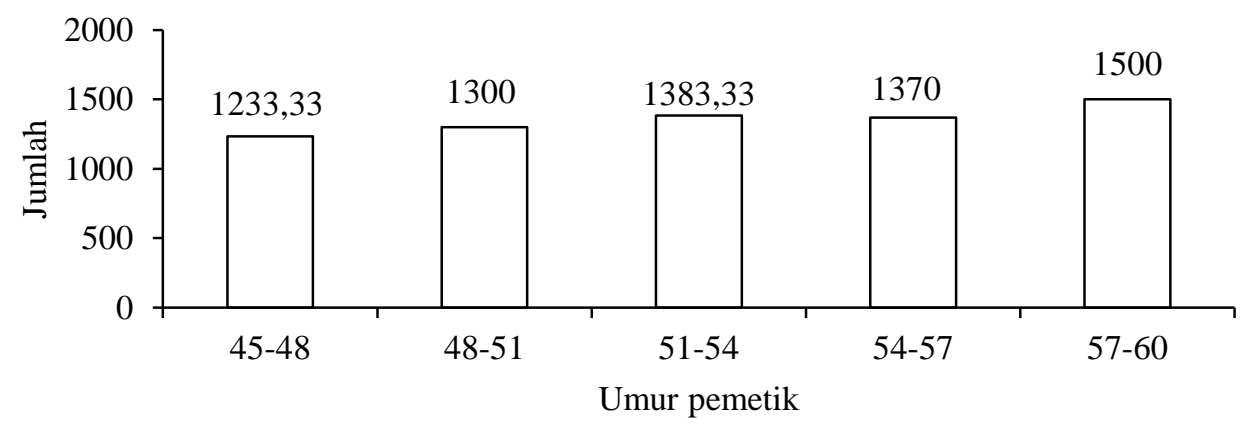

Gambar 3. Jumlah okra loss yang disebabkan oleh pemetik berdasarkan kriteria umur pemetik 
pengangkutan selama pengukuran berlangsung tidak ditemukannya jumlah loss yang ada dikarenakan proses pengangkutan sudah berjalan dengan sangat baik.

Setelah menentukan score 0,3 , dan 10 pada matriks OMAX dan telah menentukan nilai performance dari setiap KPI yang ada, serta telah melakukan perhitungan menggunakan metode OMAX pada setiap pengukuran yang dilakukan pada setiap kriteria untuk mengetahui tingkat kinerja yang dihasilkan, maka diperoleh Tabel 4. Pada KPI pemetikan terhadap kriteria berdasarkan rentang umur pekerja petik dapat diketahui bahwa jika usia pemetik bertambah tua maka score yang didapatkan juga semakin buruk (Tabel 4). Hal ini sesuai dengan pendapat Kumbadewi et al. (2016) yang menyatakan bahwa apabila usia pekerja menjelang tua maka tingkat produktivitas kerja akan semakin menurun karena keterbatasan faktor fisik dan kesehatan yang mempengaruhi. Pada KPI penimbangan untuk kriteria tenaga kerja masih mendapatkan score 6 yang artinya cukup tetapi masih belum sesuai target yang diharapkan oleh perusahaan dan pada kriteria alat timbang mendapatkan score 10. Pada KPI pengangkutan keseluruhan kriteria yang ada mendapatkan score 10 sesuai dengan target yang dinginkan oleh perusahaan yaitu loss sebesar 0 gram pada saat proses pengangkutan berlangsung.

Oleh karena itu berdasarkan tingkat kinerja yang ada dapat diketahui bahwa pada pada KPI pemetikan dan KPI penimbangan terhadap kriteria tenaga kerja masih diperlukannya perbaikan agar dapat mencapai target yang telah ditentukan perusahaan mengenai jumlah loss yang ada. Sementara pada pengangkutan sudah tidak perlu adanya perbaikan dikarenakan sudah menghasilkan tingkat kinerja yang sangat baik karena sesuai dengan target yang ditentukan.

\section{Rekomendasi Perbaikan}

Score OMAX pada KPI pemetikan dan KPI penimbangan terhadap kriteria tenaga kerja masih di bawah target yang diharapkan oleh perusahaan yaitu berada pada score 10 dengan keterangan baik (Tabel 4). Oleh karena itu perlu perbaikan terhadap proses pemetikan dan

Tabel 4. Perolehan score OMAX tiap kriteria

\begin{tabular}{llcc}
\hline No. & Kriteria & Score & Keterangan \\
\hline 1. & Pemetikan & & \\
& Usia Pemetik 57-60 Tahun & 2 & Buruk \\
& Usia Pemetik 54-57 Tahun & 2 & Buruk \\
& Usia Pemetik 51-54 Tahun & 3 & Buruk \\
& Usia Pemetik 48-51 Tahun & 4 & Cukup \\
& Usia Pemetik 45-48 Tahun & 5 & Cukup \\
2. $\quad$ Penimbangan & & \\
& Tenaga Kerja & 6 & Cukup \\
& Alat Timbang & 10 & Baik \\
3. Pengangkutan & & Baik \\
& Jarak & 10 & Baik \\
& Kondisi Jalan & 10 & Baik \\
& Tenaga Kerja & 10 & \\
\hline
\end{tabular}


Tabel 5. Rekomendasi perbaikan

\begin{tabular}{|c|c|c|}
\hline No. & Permasalahan & Rekomendasi Perbaikan \\
\hline 1. & Kurangnya ketelitian pekerja petik & $\begin{array}{l}\text { a. Meningkatkan pengawasan oleh manajer } \\
\text { lahan } \\
\text { b. Melakukan sidak }\end{array}$ \\
\hline 2. & Kurangnya pengarahan & a. Melakukan pengarahan setiap pagi \\
\hline 3. & Kecurangan pekerja petik & $\begin{array}{l}\text { a. Meningkatkan pengawasan pada pekerja } \\
\text { petik } \\
\text { b. Membuat alur perpindahan proses pemetikan }\end{array}$ \\
\hline 4. & Pemetik berusia lanjut & $\begin{array}{l}\text { a. Membuat kriteria tenaga kerja yang } \\
\text { dibutuhkan }\end{array}$ \\
\hline 5. & Kurangnya tenaga kerja timbang & a. Menambah tenaga kerja \\
\hline 6. & Okra tercecer di area penimbangan & $\begin{array}{l}\text { a. Meningkatkan pengawasan kepada pekerja di } \\
\text { area penimbangan }\end{array}$ \\
\hline 7. & Area timbang tidak rata & a. Memilih kondisi area timbang yang rata \\
\hline
\end{tabular}

penimbangan agar dapat mencapai target yang diinginkan sehingga jumlah loss yang terjadi dapat sesuai target yang ada. Rekomendasi perbaikan dapat dilakukan dengan cara memberikan kuisioner tertutup yang berisi beberapa pilihan rekomendasi perbaikan yang kemudian dapat dipilih oleh responden/narasumber terkait (manager dan asisten manager area 8) yang berada di lokasi Curahrejo, sehingga rekomendasi dapat sesuai dengan keinginan dan kebutuhan yang ada. Rekomendasi perbaikan dalam proses pemetikan yang dipilih oleh para responden terkait ditunjukkan pada Tabel 5.

Beberapa rekomendasi perbaikan yang dipilih untuk mengatasi masalah penyebab terjadinya post-harvest loss okra antara lain meningkatkan pengawasan, melakukan sidak atau inspeksi setiap minggu untuk mengatasi masalah kurang ketelitian pekerja petik, melakukan pengarahan setiap pagi, membuat alur perpindahan pemetikan serta meningkatkan pengawasan untuk mengatasi permasalahan kecurangan pemetik yang dengan sengaja meninggalkan okra untuk dipetik keesokan harinya (Tabel 5). Rekomendasi selanjutnya untuk mengatasi masalah pemetik berusia lanjut adalah dengan cara membuat kriteria tenaga kerja secara spesifik dengan mengutamakan umur produktivitas kerja. Cara mengatasi permasalahan pada proses penimbangan adalah dengan menambah tenaga kerja penimbangan dan memilih kondisi area timbang yang baik.

\section{KESIMPULAN}

Pada proses pascapanen okra terdapat 3 KPI (key performance indicator) yaitu KPI pemetikan, KPI penimbangan, dan KPI pengangkutan. Penentuan tingkat kinerja pemetik berdasarkan metode OMAX menunjukkan pada KPI pemetikan dengan kriteria berdasarkan pengelompokkan usia pemetik yaitu usia 60-57 tahun berada pada level 2 (buruk), usia 57-54 tahun berada pada level 2 (buruk), usia 54-51 tahun pada level 3 (buruk), usia 51-48 pada level 4 (cukup), dan usia 48-45 pada level 5 (cukup). Pada KPI penimbangan terhadap kriteria tenaga kerja berada pada level 6 (cukup) dan pada kriteria alat timbang berada pada level 10 (baik). Keseluruhan kriteria yang ada pada KPI pengangkutan pada level 10 dari 10 level yang ada (baik).

Beberapa rekomendasi perbaikan yang dipilih untuk mengatasi masalah penyebab terjadinya post-harvest loss yaitu 
meningkatkan pengawasan, melakukan inspeksi setiap minggu, dan melakukan pengarahan setiap pagi pada para pemetik. Pembuatan alur perpindahan pemetikan dan kriteria tenaga kerja, menambah tenaga kerja penimbangan, dan memilih kondisi area timbang yang baik juga perlu dilakukan.

\section{DAFTAR PUSTAKA}

Fithri, P., dan Firdaus, I. 2014. Analisis produktivitas menggunakan metode objective matrix (OMAX). Studi kasus: PT Marodan Berlian Sakti. Jurnal Optimasi Sistem Industri, 13 (1): 548555.

Hamid, A.A., Aiyelaagbe, O.O., Usman, L.A., Ameen, O.M., and Lawal, A. 2010. Antioxidants: Its medicinal and pharmacological applications. African $J$. Pure Appl. Chem., 4: 142-151.

Hamidah, N.H., Deoranto, P., dan Astuti, R. 2013. Productivity analysis using objective matrix (OMAX) method: Case study on the production departement of sari roti PT Nippon Indosari Corpindo, Tbk Pasuruan. Jurnal Teknologi Pertanian, 14 (3): 215-222.

Hengsdijk, H., and de Boer, W.J. 2017. Postharvest management and post-harvest losses of cereals in Ethiopia. Food Security, 9: 945-958.

Kumar, D.K., Basavaraja, H., and Mahajanshetti, S.B. 2006. An economic analysis of post-harvest losses in vegetables in Karnataka. Indian Journal of Agricultural Economics, 61 (1): 134146.

Kumbadewi, L.S., Suwendra, I.W., dan Susila, G. P. A. J. 2016. Pengaruh umur, pengalaman kerja, upah, teknologi dan lingkungan kerja terhadap produktivitas karyawan. Jurnal Jurusan Manajemen, 4 (1): 1-11.

Sa'eed, H.B., and Neela, B. 2016. Nutrient profile, bioactive components, and functional properties of okra (Abelmoschus esculentus (L.) Moench). Bioactive Foods in Health Promotion. Academic Press, US. Page 365-409.
Sabitha, V., Ramachandran, S., Naveen, K. R., and Panneerselvam, K. 2011. Antidiabetic and antihyperlipidemic potential of Abelmoschus esculentus (L.) Moench in streptozotocin-induced diabetic rats. Journal of Pharmacy and Bioallied Sciences, 3 (3): 397-402.

Sholihah, F.M. 2016. Teknik kalibrasi timbangan elektronik menggunakan metode CSIRO. Jurnal Ilmiah Teknosains, 2 (2): 126-130.

Suryaningrat, I.B., and Fianeka, A. 2017. Developing strategy for rice milling unit selection process using analytical hierarchy process (AHP) method: A Case of agroindustry in Indonesia. Advanced Science Letters, 23 (12): 11787-11792.

Winda, A. 2013. Perencanaan tools pengukuran kinerja perusahaan dan karyawan dengan menggunakan objective matrix. Jurnal Agrointek, 7 (1): 29-37.

Ramchandra, Paliwal, H., James, A., Kumar, H., Daniel, and Umrao, R. 2015. economic analysis of post-harvest losses in marketing of major vegetables in Allahabad District of Uttar Pradesh. Journal of International Academic Research for Multidisciplinary, 3 (2): 203-211. 